\title{
Determination of sulfur speciation in apatites from Martian meteorites (shergottites) using $\mu$-XANES
}

\author{
PROTEEK CHOWDHURY ${ }^{1}$, MARYJO BROUNCE ${ }^{2}$, \\ JEREMY BOYCE ${ }^{3}$ AND FRANCIS MCCUBBIN ${ }^{4}$ \\ ${ }^{1}$ University of California, Riverside \\ ${ }^{2}$ University of California Riverside \\ ${ }^{4}$ NASA Johnson Space Center \\ Presenting Author: proteekc@ucr.edu
}

${ }^{3}$ NASA

Apatite is a ubiquitous accessory mineral in planetary materials, including in Martian meteorites. Sulfur in terrestrial apatites is mostly $\mathrm{S}^{6+}$ as they are formed in relatively oxidized environments [1]. Recently, $\mathrm{S}^{2-}$-only bearing apatites have been documented in lunar and terrestrial [1] environments and in experiments [2], the later also reporting simultaneous incorporation of both $\mathrm{S}^{6+}$ and $\mathrm{S}^{2-}$ at intermediate oxygen fugacities $\left(f \mathrm{O}_{2}\right)$. Thus, it has been suggested that proportions of $\mathrm{S}^{6+} / \mathrm{S}^{2-}$ in apatite, together with major element compositions, $T$ and $P$, may record the $f \mathrm{O}_{2}$ of formation of these apatites $[1,2]$. Martian rocks, by the virtue of recording intermediate $f \mathrm{O}_{2}$ between the Moon and Earth [4], may contain $\mathrm{S}^{2-}$-only or both $\mathrm{S}^{6+}$ and $\mathrm{S}^{2-}$ bearing apatites.

Martian shergottites Shergotty and QUE 94201 record $f \mathrm{O}_{2}$ of $\sim \mathrm{IW}+1.9-\mathrm{IW}+2.8$ and $\sim \mathrm{IW}-1.5-\mathrm{IW}-1.0$, respectively [3], where we expect silicate liquids and the apatites crystallizing from those liquids to contain $\mathrm{S}$ primarily as $\mathrm{S}^{2-}$. To test this hypothesis, we present S-XANES measurements of apatite grains and other associated phases.

Shergotty apatites only show peaks of structural $\mathrm{S}^{2-}$ in apatites ( 2470 and $2477 \mathrm{eV}$ ) with $\mathrm{S}^{6+} / \sum \mathrm{S}=0$. The presence of $\mathrm{S}^{2-}$-only apatites in Shergotty is consistent with other mineralogical records of $f \mathrm{O}_{2}$ in this meteorite and suggest that the oxidation state of sulfur records and preserves the $\mathrm{fO}_{2}$ during igneous crystallization of apatite. QUE 94201 apatites, however, show peaks of both $\mathrm{S}^{2-}$ and $\mathrm{S}^{6+}(2481.7 \mathrm{eV})$, varying in $\mathrm{S}^{6+} / \sum \mathrm{S}$ from 0 $100 \%$. This meteorite is known to have gone through substantial sulfate-rich alteration and oxidation both on the fusion crust and in the interior upon arrival to Earth's surface [4]. The oxidized nature of apatites, when considered together with the low $f \mathrm{O}_{2}$ recorded by the meteorite and reduced nature of apatites from minimally altered Shergotty and lunar rocks suggest that these measurements and/or the apatite grains themselves are subject to contamination by secondary oxidative alteration events on Earth and/or Mars.

[1] Brounce M. et al. (2019) Am. Min., 104, 307-312. [2] Konecke B.A. et al. (2019) Geochim. Cosmochim. Acta, 265, 242-258. [3] Wadhwa M. (2001) Science, 291, 1528-1530. [4] Ross et al. (2010) LPSC 2010. 